\title{
Archaeological Investigations at 34WG220: A Prehistoric Occupation in the Arkansas River Valley of Eastern Oklahoma
}

Robert Bartlett

Unknown

Follow this and additional works at: https://scholarworks.sfasu.edu/ita

Part of the American Material Culture Commons, Archaeological Anthropology Commons, Environmental Studies Commons, Other American Studies Commons, Other Arts and Humanities Commons, Other History of Art, Architecture, and Archaeology Commons, and the United States History Commons

Tell us how this article helped you.

This Article is brought to you for free and open access by the Center for Regional Heritage Research at SFA ScholarWorks. It has been accepted for inclusion in Index of Texas Archaeology: Open Access Gray Literature from the Lone Star State by an authorized editor of SFA ScholarWorks. For more information, please contact cdsscholarworks@sfasu.edu. 


\section{Archaeological Investigations at 34WG220: A Prehistoric Occupation in the Arkansas River Valley of Eastern Oklahoma}

\section{Creative Commons License}

\section{(c) (1) (8)}

This work is licensed under a Creative Commons Attribution-NonCommercial 4.0 International License 


\title{
Archaeological Investigations at 34WG220: A Prehistoric Occupation in the Arkansas River Valley of Eastern Oklahoma
}

\author{
by \\ Robert Bartlett, \\ Oklahoma Highway Archaeological Program
}

\section{Introduction}

In January and February of 1997, the Oklahoma Department of Transportation (ODOT) conducted archaeological work at site 34 WG220 within right-of-way for a project involving realignment of $\mathrm{SH}-72$ just south of Coweta, Wagoner County, Oklahoma. The site investigation consisted of the monitoring of trench excavation as well as controlled machine stripping. A few prehistoric artifacts, none of which are diagnostic, were found during the investigation. However, two cultural features were discovered during the monitoring of the trench excavation. The features were investigated by hand excavation of a $1 \times 2$ test unit.

\section{Site Setting}

Environment Site 34 WG220 occurs on an upper terrace about $1.04 \mathrm{~km}$ north of the present channel of the Arkansas River. Coweta Creek, flowing southward toward the river, passes about $100 \mathrm{~m}$ east of the site. The creek is deeply entrenched adjacent to the site, exposing shales and sandstones of the Pennsylvanian age Senora and Boggy Formations (Marcher 1969).

Several small drainages occur in the vicinity, many of which are spring fed. The landowners report that a spring once flowed just north of the site and a that considerable amount of subsurface water was observed flowing toward Coweta Creek at the base of the trench adjacent to the county road south of the site. The terrace deposits on which the site occurs are considered as very favorable for groundwater supplies (Marcher 1969).

The terrace is presently covered in a mixture of hardwood timber and grasses. The area is part of the Cherokee Prairie biotic district (Blair and Hubbell 1938: 
431-433). The district is characterized by tall grasses including bluejoint (Andropogon furcatus), prairie beardgrass (Andropogon scoparius), and switchgrass (Panicum virgatum), which become mixed with short grasses including side-oats grama (Bouteloua curtipendula), buffalo grass (Buchloe dactyloides), and silver beardgrass (Andropogon sacchariodes) on thinner soils. Floodplain, stream margins, and sheltered ravines support forest, including a variety of oaks (Quercus stellata, $Q$. marilandica, $Q$. shumardii and Q. muhlenbergii), hickory (Carya buckleyi), elm (Ulmus americana, U. fulva), hackberry (Celtis occidentalis and $C$. laevigata), willow (Salix nigra), cottonwood (Populus deltoides), and silver maple (Acer saccharinum). Small trees such as persimmon (Diospyros virginiana) and sumac (Rhus glabra and R. copallina) are also common.

The combination of forest and prairie habitat has been known historically to support a diversity of faunal resources. Historical accounts by early explorers to the region such as Colonel A. P. Chouteau note the presence of deer, elk, bear and buffalo (Foreman 1934:148). The faunal assemblage recovered at the Lasley Vore site (34TU65), a Protohistoric period village site along the Arkansas River near Jenks, Oklahoma, attests to the variety of game available in the area just prior to the intensive 19th and 20th century settlement of the area (Odell 1989). Remains of large mammals such as bison (Bison bison), white-tailed deer (Odocoileus virginianus), bear, (Ursus americanus), and cougar
(Felis concolor) were recovered, as well as smaller animals such as bobcat ( $\operatorname{Lyn} x$ rufus), beaver (Castor canadensis), cottontail (Sylvilagus floridanus), opossum (Didelphis virgininaus), turkey (Meleagris gallopavo), and box turtle (Terrapene sp.; Yates and Brown 1989: 111).

Soils The site occurs on soils within the Kamie-Newtonia-Okay association. These soils developed in loamy and sandy sediments under grasses and hardwood forest (Polone 1976:4). The soil series occurring on the site area is Kamie fine sandy loam (Polone 1976: Sheet 28). This soil developed from remnant dune material deposited on the terrace from the nearby Arkansas River. The basic soil profile observed along the trench appears to be typical of that described for Kamie series soils (Polone 1976:14-15). The soil profile examined in the excavated trench consists of an upper horizon of about 60 $\mathrm{cm}$ of homogeneous unconsolidated brown sandy loam with a clear smooth boundary, above about $10-15 \mathrm{~cm}$ of reddish sandy clay loam, which transitions into a reddish clay loam with some sand present to the bottom of the trench about $180 \mathrm{~cm}$ below the surface. A slight change in the profile occurs in the northern portion of the trench as it bisects the higher elevation closer to the top of the hill (approximately the northern 1/3 of the trench). Through this area a darker brown sandy loam is visible in the upper $20 \mathrm{~cm}$. This horizon diffusely transitions into the general homogeneous unconsolidated brownish sandy loam described earlier. The sandy loam extends to about $60 \mathrm{~cm}$ 
Volume 9, Number 2

below the surface; however the lower 10$15 \mathrm{~cm}$ of this material becomes lighter and more loamy. In addition the reddish clay underlying the sandy loam becomes less sandy and in places is underlain by a yellow clay.

\section{Archaeological and Historical Background}

Information regarding prehistoric occupations within this particular portion of the Arkansas River valley is scanty. However, there is evidence of occupations in the general area spanning an expansive time frame. Archaeological investigations at the Day site (34WG171), located on uplands adjacent to the Arkansas River about $4 \mathrm{~km}$ west of $34 \mathrm{WG} 220$, documented the occurrence of Dalton-like bifaces and drills (Odell and Vereecken-Odell 1989). Similar bifaces have been recovered from the Packard site (34MY66) located on the west edge of the Ozark Plateau about 55 $\mathrm{km}$ east of the site (Wyckoff 1985). The stratum from which they were recovered has been radiocarbon dated to about 9600 years ago (Wyckoff 1989). This stratum is just above one containing and hearth dated to 9800 years ago around which a sidenotched and several lanceolate bifaces were recovered (ibid).

The Brandon site (34TU82), located about $35 \mathrm{~km}$ northwest of $34 \mathrm{WG} 220$, has produced evidence of Middle Archaic occupations on uplands within $3.5 \mathrm{~km}$ of the Arkansas River (Neal 1994). Here, basally-notched bifaces attributable to the Calf Creek horizon have been found. The makers of these bifaces are thought to have occupied the region between 5000 and 6000 years ago (Wyckoff 1995).
Several sites along the western margin of the Ozark Plateau about 35 to $45 \mathrm{~km}$ east of $34 \mathrm{WG} 220$ are known to contain artifacts evidencing Late Archaic occupations (Wyckoff et al. 1963); however, sites investigated in the vicinity of 34 WG 220 attributable to this age are few. The diagnostic bifaces recovered suggest Late Archaic occupations may be manifest at 34 WG108 in the Kadashan bottoms about $8 \mathrm{~km}$ west of 34 WG220 (Wallis 1984). Several burned sandstone features were excavated at this site, some of which may date to Late Archaic occupations (ibid). Excavations at the W. W. Works site (34WG117) revealed a similar burned sandstone feature (Mclung 1980). Diagnostic bifaces recovered from the surface of this site suggest the feature may relate to a Late Archaic occupation.

The previously discussed excavations at the Day site (34WG171) also produced evidence of Late Archaic/Woodland occupations. The recovery of contracting stemmed and corner-notched bifaces, corner-notched arrow points and cordmarked pottery sherds suggest that people with Late Archaic/Woodland adaptations visited the site (Odell and VereeckanOdell 1989:42).

Late prehistoric sites also are not well 
documented in the area. A radiocarbon date obtained from Feature 2, associated with Component 6 at the previously discussed Kadashan Bottoms site (34WG108), suggests that in addition to a Late Archaic component, occupation of this site also occurred around $\mathrm{AD} 1415$ (Wallis 1984:94). Several late prehistoric sites are known to occur in the Arkansas River drainage to the southeast. Important sites relating to the Harlan and Spiro phase occupations are located along the Neosho River $50 \mathrm{~km}$ east of $34 \mathrm{WG} 220$ (Bell 1984; Brown 1984). Several mound centers, villages and small hamlets of both phases have been investigated and attest to an intense occupation within the eastern Arkansas River basin of Oklahoma by Caddoan groups between AD 900-1450 (ibid).

The Lasley-Vore site (34TU65) represents a Protohistoric village on the Arkansas River about $25 \mathrm{~km}$ northwest of 34WG220 (Odell 1989). Extensive arch- aeological work revealed a large village likely visited and occupied by indigenous groups with wide ranging contacts. The site may possibly be the location of or at least contemporary with a Tawakoni (Wichita) village visited by Jean-Baptiste Benard, Sieur de la Harpe in 1719 (Odell 1989:88).

As part of the area for removal of indigenous population from the southeastern United States about 1834, this area became part of the Muscogee (Creek) Nation. The town of Coweta was established by members of the nation around this time. The town's ceremonial center and ball ground were located north of 34WG220. The Koweta mission and school was established by Reverend R. M. Loughridge in 1842 about $1.5 \mathrm{~km}$ to the west of 34 WG220 (Foreman 1948). The mission and school operated until the onset of the Civil War. A cemetery associated with the mission is still visible today.

\section{Excavation of Cultural Features at 34WG220}

Two cultural features were identified during the monitoring of a sewer line trench excavation. The features were identified on the north wall of the area excavated for the manhole in which a sewer line terminates. The larger feature (Feature 1) was observable in profile at about $50 \mathrm{~cm}$ below the surface as an approximately $10 \mathrm{~cm}$ thick lens of charcoal stained soil about $90 \mathrm{~cm}$ in length east/ west (Figure 1). The lens contained sev- eral fragments of burned sandstone. A few pieces of sandstone occurred outside of, but in the general vicinity of, the lens. The feature occurs near the base of the upper soil zone consisting of a medium brown fine sandy loam. Immediately below the feature is light-brown silty loam which occurs upon a reddish yellow sandy clay. Seven pieces of fire cracked sandstone were collected during initial examination and cleaning of the feature's profile. 


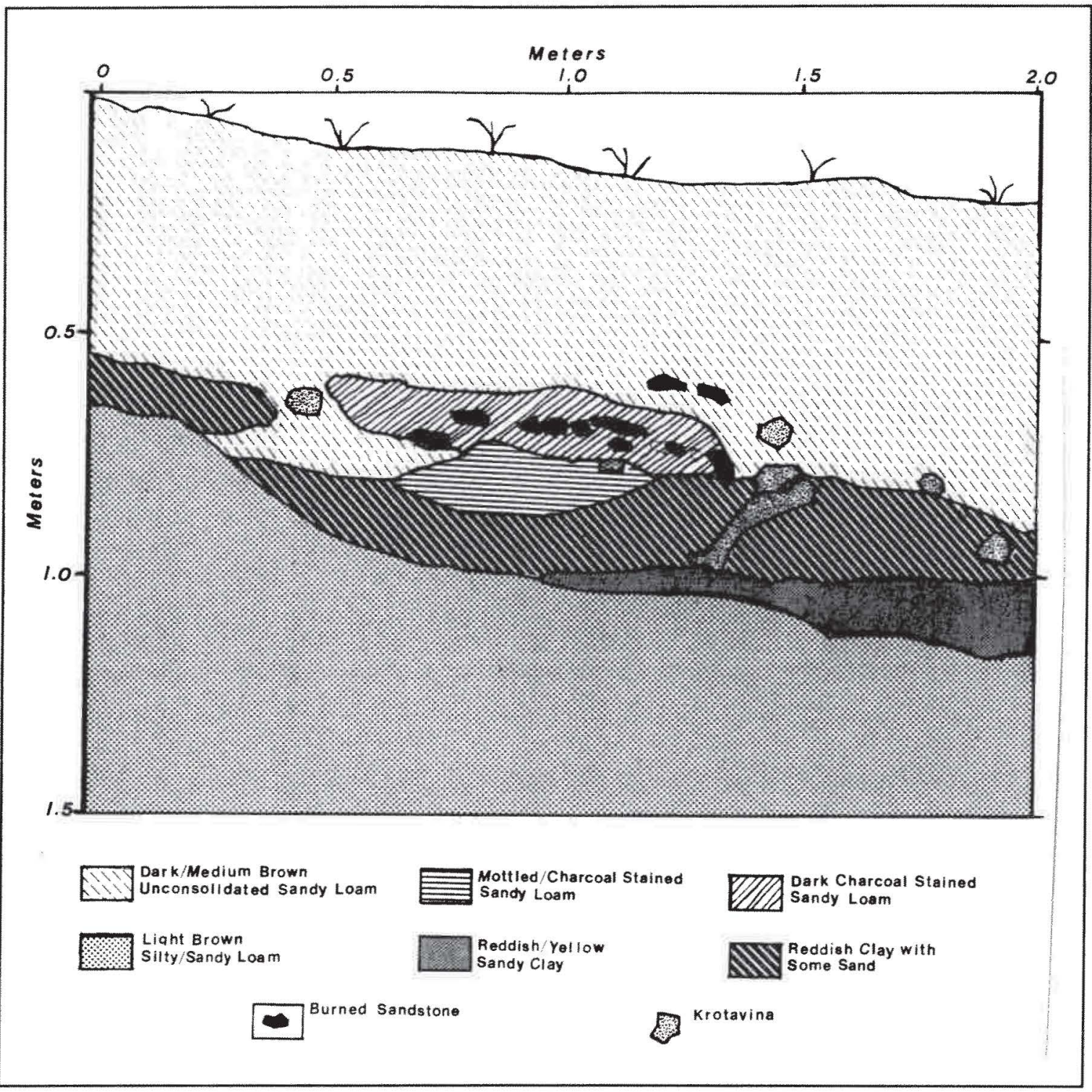

Figure 1. Feature I Profile in North Trench in Relation to Test Unit A and Vertical Control Datum (Level String Line from Northwestern Corner of Unit).

A second feature (Feature 2) was identified on a ledge just above the floor of the trench immediately south of and below the feature described above. This feature was observed in plan view at about $90 \mathrm{~cm}$ below the surface. In relation to the east/west profile of the feature previously described, it occurs about midway along its length, in an area $10-20 \mathrm{~cm}$ to the south and about $30 \mathrm{~cm}$ below the base of Feature 
1. The feature is distinguishable as an oval area of brown sandy loam extending into reddish yellow sandy clay. The feature is oval in outline and about $25 \mathrm{~cm} \times 17 \mathrm{~cm}$. An in situ cobble of Boone chert (Keokuk variety), from which two flakes have been removed, is positioned on it's edge within and against the west edge of the feature. In addition, three cobbles of Boone chert (Keokuk variety), one of which is broken and the other two unmodified, were recovered while cleaning off loose dirt just above the feature (Table 1).

Excavation of Features A $1 \times 2 \mathrm{~m}$ test unit (Test Unit A) was opened to uncover and investigate the features. The unit was excavated in three levels. A level string line was established east to west on the north wall of Test Unit A to serve as a vertical control datum. All levels evidenced a high degree of rodent disturbance. Level 1 was excavated to $40 \mathrm{~cm}$ below the datum (BLD) and, with the exception of one small flake of thermally altered Boone chert recovered from a rodent burrow at the base of the unit, only historic/modern artifacts were recovered from this level (Table 1). These items include fragments of clear glass $(n=7)$, brown glass $(n=1)$ and light green $(n=2)$ glass jar and bottle fragments, seven fragments of window pane glass (one of which has raised decorations), a light bulb fragment, a marble, three round wire nails, a wire fragment, three fragments of whiteware, seven pieces of coal and eight unidentifiable burned/slag items. Other items recovered include unmodified sandstone $(\mathrm{n}=12)$ and gravel $(n=7)$.
Level 2 was excavated from $40 \mathrm{~cm}$ to 53 $\mathrm{cm}$ BLD, ending when the top of the feature was encountered. Artifacts recovered from this level include three clear glass bottle/jar fragments, one fragment of window glass, five round wire nails, a wire fragment, and four unidentified burned/slag items (Table 1). In addition, unmodified gravel $(n=3)$, sandstone $(n=3)$, and black walnut shell were recovered. The walnut shell recovered from a rodent burrow is unburned, and appears to be very modern.

Level 3 was excavated from $53 \mathrm{~cm}$ to 80 $\mathrm{cm}$ BLD and included all of Feature 1. Although the feature was relatively intact, the area surrounding the feature had been heavily disturbed by rodent activity. The disturbance was active, and it was necessary to clean dirt mounded on and around the feature every morning prior to excavation and at times during excavation. Likely as a result of such disturbance, one clear glass bottle/jar fragment, a wire fragment, two pieces of slag and three pieces of asphalt shingle were recovered from this level (Table 1). However, this level also produced the greatest number of prehistoric artifacts. These items are described below in the discussion of Feature 1.

Feature 1 The feature was revealed to be a circular stone hearth/oven about $1 \mathrm{~m}$ in circumference east/west and about $70 \mathrm{~cm}$ north/south (Figure 2). A small portion of the feature in the latter direction was affected by trench excavation. The hearth was constructed of tabular sandstone 
Table 1. Artifacts recovered during investigations at $34 W G 220$.

\begin{tabular}{|c|c|c|c|c|c|c|c|c|}
\hline \multirow[t]{2}{*}{ Artifacts } & \multicolumn{2}{|c|}{ Monitor } & \multicolumn{3}{|c|}{ Test Unit A } & \multicolumn{2}{|c|}{ Feature 2} & \multirow[t]{2}{*}{ Total } \\
\hline & Trench & Blading & Level 1 & Level 2 & $\begin{array}{l}\text { Level } 3 \\
\text { (Feat. 1) }\end{array}$ & Cleaning & Excavation & \\
\hline $\begin{array}{l}\text { Historic } \\
\text { Glass jar/bottle fragments }\end{array}$ & & & 10 & 3 & 1 & & & 14 \\
\hline Window glass fragments & & & 7 & 1 & & & & 8 \\
\hline Light bulb fragments & & & 1 & & & & & \\
\hline Ceramic fragments & & 3 & 3 & & & & & 6 \\
\hline Nails & & & 3 & 5 & & & & 8 \\
\hline Wire & & & 1 & 1 & 1 & & & 3 \\
\hline Marble & & & 1 & & & & & 1 \\
\hline Coal & 1 & 7 & & & & & & 8 \\
\hline $\begin{array}{l}\text { Unidentified burned/ } \\
\text { slag items }\end{array}$ & & & 8 & 4 & 2 & & & 14 \\
\hline $\begin{array}{l}\text { Prehistoric } \\
\text { Flakes }\end{array}$ & 2 & 2 & 1 & & 3 & & & 8 \\
\hline Biface fragment & & & & & 1 & & & 1 \\
\hline Hammerstone fragment & 1 & & & & & & & 1 \\
\hline Anvil stone & 1 & & & & & & & 1 \\
\hline $\begin{array}{l}\text { Chert cobbles } \\
\text { Unmodified } \\
\text { Modified }\end{array}$ & 2 & & & & & 3 & 1 & 1 \\
\hline Total & 7 & 5 & 42 & 14 & 8 & 3 & 1 & 80 \\
\hline
\end{tabular}

placed within a shallow basin the base of which is about $77 \mathrm{~cm}$ BLD. With the exception of an area encompassing the approximate center of the hearth, tabular pieces of sandstone were present throughout the feature, becoming less numerous toward the base. Some stones have been removed from the center of the feature and apparently piled on the west edge of the feature. Although some stones were encountered in the central area, the soil is mottled and contains less charcoal than the surrounding fill. The apparent removal of stones and the mottled soil/hearth fill in this area may be an indication that the feature served as an oven with the center 




Figure 2. Feature 1 as Uncovered at $53 \mathrm{~cm} \mathrm{BLD} \mathrm{(Note} \mathrm{Rodent} \mathrm{Disturbance).}$

stones removed as a result of activity related to cooking. Among the stones throughout most of the feature is a dark soil containing a dense concentration of charcoal. Larger pieces of charcoal derived from small logs were encountered toward the base of the feature. Samples of the dark stained soil comprising the hearth fill were collected for flotation analysis in hopes of recovering charred plant remains.

Hearthstone A total of 312 pieces of sandstone weighing approximately 35.43 $\mathrm{kg}$ was recovered from Feature 1. The stones are mostly tabular and likely collected from local sandstone exposures, several of which occur along nearby Coweta Creek. All stones over $10 \mathrm{~cm}$ in length were selected for thickness measurements. A total of 65 stones were measured and range from 8.6 to $0.6 \mathrm{~cm}$ in thickness with a mean of $2.4 \mathrm{~cm}$ and standard deviation of 1.31 . These numbers indicate a fair consistency in thickness. This consistency may be due to several factors, including natural size of stone at 
Volume 9, Number 2

local outcrops, selection of stones of consistent size for specific purpose, or fracturing along structural planes within the stone as a result of exposure to heat.

Artifacts A total of four prehistoric artifacts was recovered during excavation of Feature 1 (Table 1). A flake of Ogallala quartzite was recovered from the hearth fill; two flakes and an edge of a thick biface, all of which are of Boone chert (Reed Springs variety), were recovered in areas adjacent to the hearth. Although the artifacts were recovered at the same level as (Level 3) and adjacent to Feature 1, the area around the feature has been heavily disturbed by rodent activity and their direct association is questionable.

Floral and Flotation Analysis Among the larger pieces of charcoal recovered from Feature 1, elm (Ulmus sp.), maple (Acer sp.) and oak (Quercus sp.) were identified. A total of eight, two liter samples of fill from Feature 1 were subjected to flotation, one of which was selected for analysis by a full sort. The samples were weighed, and both light and heavy fractions were processed through nested geological screens of $2 \mathrm{~mm}, 1 \mathrm{~mm}$ $0.5 \mathrm{~mm}$ and $0.25 \mathrm{~mm}$. All material from each screen of the sample selected for a full sort was examined under a binocular microscope at 10-25 $\mathrm{x}$ magnification. Selected portions of the remaining samples were scanned under magnification. Each sample contained large amounts of charcoal fragments, and contamination by volume of each sample is less than $25 \%$, most of which is rootlets. No charred seeds, bone or artifacts were observed in the fully sorted or scanned samples.

Radiocarbon Date A considerable amount of charcoal was recovered from the hearth fill, including several large pieces. A $9.5 \mathrm{gm}$ charcoal sample derived from a small maple log from an undisturbed portion of Feature 1 was submitted for radiometric dating. The resulting date, adjusted according to measured $\mathrm{C} 13 / \mathrm{C} 12$ ratios, is $630 \pm 60$ radiocarbon years $\mathrm{BP}$ (Beta-102887). Calibrated dates of AD $1310,1353,1385$ with a two sigma range of AD 1280-1427 were calculated (Stuiver and Pearson 1993).

Feature 2 Excavation of Feature 2 revealed very little additional information beyond that derived from its initial discovery. The base of the feature was encountered about $5 \mathrm{~cm}$ below the level (117 cm BLD) at which it was identified. Since little of the feature remained, it is difficult to interpret. However, two possibilities are plausible. One is that the feature is the base of a post mold with the in situ chert cobble, and the others recovered while cleaning the area above the feature, serving to secure the post in the hole. Although it is doubtful that a historic/modern fence post would extend to $117 \mathrm{~cm}$ (46 inches) in depth, the possibility does exist. However, the fact that the in situ chert cobble exhibits two flake scars typical of prehistoric technology lends doubt to this interpretation, and suggests a prehistoric origin for the post mold. Another possibility is that the feature is a cache pit containing the chert 
cobbles. Since stream transport of the cobbles upstream from outcrops $35 \mathrm{~km}$ east of the site is not possible, the cobbles could only be transported to the site by people. Thus storage of these items on site for use as a ready source of tool stone by the sites' occupants is plausible. One problem with this interpretation is that although the one cobble recovered from the feature has been flaked, the remaining ones are un- modified and all are of low quality chert poorly suited for production of stone tools. However, it is possible the material was intended for heat treatment to enhance its knappability. The recovery of a small flake derived from thermally altered Boone chert in Level 1 of Test Unit A attests to the occurrence of heat-treated material on the site.

\section{Interpretations and Conclusions}

Lacking the recovery of diagnostic prehistoric artifacts in association with the features, the radiometric date obtained from Feature 1 provides the only means of temporal assessment. The sample was derived from a single piece of charcoal and due to very little disturbance of the feature itself, the possibility of contamination is minimal. Therefore, the calibrated date of ca. AD 1350 derived from the sample is not unreasonable. However, a collection of artifacts found in the vicinity over many years by the landowners is more typical of earlier occupations, possibly Late Archaic or Woodland. Although exact provenience of these items is unknown, many of the artifacts reportedly were found west of the area investigated. Thus there is the likelihood of more than one occupation on the site.

The lack of artifacts recovered from the features during the investigation suggests that they are not the result of an intensive occupation within the area examined. In addition, Feature 1 does not evidence re- peated use and is more likely to be the result a single use event. Such a function would be more expected to be associated with a temporary camp. Although the feature appears to have served in some way as a cooking feature, the lack of charred seeds or nut hull in the flotation samples suggests the feature may not have been used in processing such items. Based on the minimal amount of data recovered by this investigation, the most feasible interpretation is that the hearth/oven feature is the result of activity associated with a temporary camp occupied around AD 1350. Wallis $(1984: 94,106)$ suggests a similar pattern of occupation for all components at 34WG108 in the nearby Kadashan Bottom. Although the lithic assemblage recovered from $34 \mathrm{WG} 220$ is small, all but one of the items are Boone chert, the closest sources of which occur about $35 \mathrm{~km}$ east of the site on the western edge of the Ozark Plateau. If the items are associated with the use of the hearth/oven feature, this would suggest the site's inhabitants responsible for Feature 1 
Volume 9, Number 2

arrived on the site from areas to the east. However, due to the high degree of soil disturbance revealed by the excavations, their association with the feature is questionable.

The floral analysis provides limited but useful information. The identification of elm, oak and maple among the charcoal recovered from the hearth indicates that a diverse forest, very similar to that which exists today, was present along the Arkansas River valley in this area around AD 1350. The presence of diverse forest along this portion of the Arkansas River provides evidence that the local environment may have been little affected by drier conditions thought to have predominated in the region during this time (Hall 1988:208-209).

The majority of historic/modern items recovered, including clear glass bottle/jar fragments, round wire nails, light bulb fragment and a glass marble, appear to be relatively late in age and likely relate to ongoing occupations on the site over the last 40 years. The coal and few ceramic fragments recovered may derive from these or slightly earlier occupations. However, none bear distinctive makers marks or manufacturing techniques allowing more definitive date ranges.

\section{References Cited}

Bell, R. E.

1984 Arkansas Valley Caddoan: The Harlan Phase. In Prehistory of Oklahoma, edited by R. E. Bell, pp. 221-240. Academic Press, Orlando.

\section{Brown, J. A.}

1984 Arkansas Valley Caddoan: The Spiro Phase. In Prehistory of Oklahoma, edited by R. E. Bell, pp. 241-263. Academic Press, Orlando.

Blair, F. W. and T. H. Hubbell

1938 The Biotic Districts of Oklahoma.

The American Midland Naturalist 20:425-454.

Foreman. C. T.

1948 Report of the Reverend R. M. Loughridge to the Board of Foreign
Missions Regarding the Creek Mission. The Chronicles of Oklahoma 26(3):278-285.

Foreman, G.

1934 The Five Civilized Tribes. University of Oklahoma Press, Norman.

Hall, S. A.

1988 Environment and Archaeology of the Central Osage Plains. Plains Anthropologist 33(120):203-218.

Marcher, M. V. 1969 Reconnaissance of the Water Resources of the Fort Smith Quadrangle, East Central Oklahoma. Hydrologic Atlas 1. Oklahoma Geological Survey, University of Oklahoma, Norman. 
McClung, T. L.

1980 A Preliminary Report: Archaeological Investigations at the W. W. Works Site, 34WG117, Northeast Oklahoma. Oklahoma Anthropological Society Newsletter 28(1):2-6.

Neal, L.

1994 The Brandon Site, 34TU82, Tulsa County, Oklahoma. Bulletin of the Oklahoma Anthropological Society 40:209-249.

Odell, G. H.

1989 Final Report on Archaeological Excavations Conducted Between May and July, 1988, at the Lasley Vore Site (34TU65), Jenks, Oklahoma. Report prepared for Kimberly-Clark Corporation, the Oklahoma State Archaeologist, and the Oklahoma State Historic Preservation Office. Tulsa, Oklahoma.

Odell, G., P. Arias, D. Hagen and D. Gaston

1988 An Archaeological Survey of Western Wagoner County. Department of Anthropology, University of Tulsa, Contributions in Archaeology No. 16.

Odell, G., and Frieda Vereecken-Odell 1989 First Impressions and Ultimate Reality: Excavation of the Day Site in Wagoner County, Oklahoma. Bulletin of the Oklahoma Anthropological Society $38: 19-48$.

Polone, D. J.

1976 Soil Survey of Wagoner County.
Soil Conservation Service, United States Department of Agriculture.

Stuiver, M. and G. W. Pearson

1993 High-Precision Bidecadal Calibration of the Radiocarbon Time Scale, AD 1950-500 BC and 25006000 BC. Radiocarbon 35:1-23.

Wallis, C. S., Jr

1984 Reanalysis and Report on Findings of Work Conducted at 34WG108, Kadashan Bottom Watershed, Southwestern Wagoner County. Oklahoma Conservation Commission, Archaeological Research Report No. 12. Oklahoma City.

Wyckoff D. G.

1985 The Packard Complex: Early Archaic, Pre-Dalton Occupations on the Prairie-Woodlands Border. Southeastern Archaeology 4:1-26.

1989 Accelerator Dates and Chronology at the Packard Site, Oklahoma. Current Research in the Pleistocene 6:2426.

1995 A Summary of the Calf Creek Horizon in Oklahoma. Bulletin of the Oklahoma Anthropological Society 42:179-210.

Wyckoff, D. G., P. Robison and T. P Barr 1963 The Archaeological Resources of the Markham Ferry Reservoir Area Mayes County, Oklahoma. Oklahoma River Basin Survey Project General Survey Report 
No. 1. University of Oklahoma Research Institute, Norman, Oklahoma.

Yates, B. C. and M. E. Brown

1989 Appendix I Faunal Analysis. In Final Report on Archaeological Exca- vations Conducted Between May and July, 1988, at the Lasley Vore Site (34TU65), Jenks Oklahoma, by George Odell. Report prepared for Kimberly-Clark Corporation, the Oklahoma State Archaeologist, and the Oklahoma State Historic Preservation Office. Tulsa, Oklahoma. 